\title{
Phytoconstituents and Biological Activities of Zanthoxylum armatum Fruit Extract
}

\author{
Ishwor Pathak*1, Shusma Rokaha ${ }^{1}$, Kiran Bahadur Bajracharya ${ }^{1}$ \\ ${ }^{1}$ Department of Chemistry, Amrit Campus, Tribhuvan University, Kathmandu, Nepal \\ *Corresponding E-mail: pathakishwor14@gmail.com \\ (Received: September 30, 2020; Revised: January 5, 2021; \& Accepted: January 15, 2021)
}

\begin{abstract}
The essential oil and methanol extract of the fruit of Zanthoxylum armatum DC were extracted by hydrodistillation in the Clevenger apparatus and cold percolation technique respectively and their chemical and biological studies were performed. The chemical compositions of essential oil were analyzed by GC-MS analysis. The most abundant ingredient was linalool (75.31\%) followed by E-methyl cinnamate (11.73\%) and limonene $(9.45 \%)$. The nature of the functional groups present in the extract was analyzed by performing FTIR analysis. The methanol extract showed the presence of alkaloids, flavonoids, glycosides, polyphenols, terpenoids, volatile oils, tannins, and saponins. Biological activities of the oil and extract were evaluated by performing brine shrimp bioassay, antibacterial activity test, and antifungal activity test. Essential oil $\left(\mathrm{LC}_{50}=\right.$ $76.70 \mu \mathrm{g} / \mathrm{mL})$ and methanol extract $\left(\mathrm{LC}_{50}=62.25 \mu \mathrm{g} / \mathrm{mL}\right)$ were found highly cytotoxic against brine-shrimp nauplii. The essential oil showed potent antibacterial activity against gram-positive bacteria Bacillus subtilis, Micrococcus leutus, and Staphylococcus aureus with the zone of inhibitions $11 \mathrm{~mm}, 16 \mathrm{~mm}$, and $17 \mathrm{~mm}$ respectively and moderate antibacterial activity against the gram-negative bacteria Klebsiella pneumonia, Enterobacter cloacae, and Pseudomonas aeruginosa with the zone of inhibitions $9 \mathrm{~mm}, 5 \mathrm{~mm}$ and $6 \mathrm{~mm}$ respectively. The methanol extract was found to be effective against gram-positive bacteria only. Both oil and extract showed moderate antifungal activity against bacterial strains.
\end{abstract}

Keywords: Zanthoxylum armatum, essential oil, extract, GC-MS analysis, antibacterial

\section{Introduction}

The genus Zanthoxylum armatum DC belongs to the family Rutaceae is a sub deciduous, xerophytic, aromatic, and branched tree or shrub[1]. It is known as "Timoor" in Nepali, Tejphal in Hindi, Tejovati, or Tumbru in Ayurved, and Prickly ash in English. It has a maximum length of up to about $5 \mathrm{~m}$ with compound, alternate imparipinnate leaves, and flowers are minute, polygamous, and pale yellow [2]. Fruits are drupe and small with red color, splitting into two when ripe [3]. Seeds are shining black, rounded, and non-endospermic [4]. It is mostly distributed in the Himalayas from Jammu to Bhutan, Nepal, Pakistan, India, and some other countries at an altitude up to $2500 \mathrm{~m}$. In Nepal, it is distributed from east to west at an elevation range of $1100-2500 \mathrm{~m}$ [5].

The different parts of this plant such as leaves, fruits, seeds, stem, bark, and roots have been used for the treatment of various ailments and their significant medicinal properties were further reported through various scientific investigations
[6]. It shows antioxidant, anti-inflammatory, analgesics, antimicrobial and insecticidal activity. Various scientific investigations revealed that $Z$. armatum is more effective for the treatment of liver (hepatoprotective), controlling diabetes and blood pressure [6]. It is also used for the treatment of pneumonia, teeth infection, curing gum diseases, stomachache, gas problems, indigestion, and as a carminative [7]. Its fruits and seeds are edible and are used as potherb spices and flavoring agents [8]. Seeds of this aromatic plant contain mainly volatile oils and different phytoconstituents like alkaloids, tannins, terpenoids, glycosides, amino acids are present in leaf and seed extracts [9]. In this study, the extract was prepared and essential oil was extracted from Zanthoxylum armatum fruits.

\section{Materials and Methods}

\section{Collection of plant materials}

The fresh fruits of Zanthoxylum armatum DC were collected from Lalitpur district, Nepal (altitude 1400m) in September 2018. The taxonomic identification of 
the plant was confirmed at the Department of Botany, Amrit Campus, Kathmandu, Nepal.

\section{Extraction process}

The essential oil from the fruits (500 g) of Zanthoxylum armatum was extracted by hydrodistillation for 6 hours using a closed type Clevenger apparatus for extraction of oils lighter than water. The collected oil was dried over anhydrous $\mathrm{Na}_{2} \mathrm{SO}_{4}$ and stored at $5{ }^{\circ} \mathrm{C}$ until analysis. The marc was subjected to a cold percolation technique using methanol as solvent $(500 \mathrm{~mL} \times 24 \mathrm{hrs} \times 5$ times $)$. The methanol extract was concentrated using a rotary evaporator. The concentrated extract was dried and stored in a sealed glass vial in a refrigerator until further experiment was performed.

\section{Phytochemical screening}

The methanol extract of the fruit was subjected to various qualitative tests by following a standard protocol to identify the presence of different classes of secondary metabolites present in the extract [10].

\section{Gas chromatography-mass spectrometry(GC-MS) analysis}

The qualitative and quantitative analysis of extracted essential oil of $Z$. armatum was performed on Shimadzu made GC-MS equipped with RTX-5 MS column $(30 \mathrm{~m} \times 0.25 \mathrm{~mm}$ internal diameter, $0.25 \mu \mathrm{m}$ film thickness). Helium was used as a carrier gas at a flow rate of $1 \mathrm{~mL} \mathrm{~min}{ }^{-1}$. An injection volume of the sample was $1 \mu \mathrm{L}$ with a split ratio of $1: 90$. The initial column temperature was maintained at $40{ }^{\circ} \mathrm{C}$. The instrument was operated in the electron impact (EI) mode of ionization at $70 \mathrm{eV}$ and ion source temperature $170{ }^{\circ} \mathrm{C}$. Volatile constituents of the oil were identified by comparing the mass spectra available in a database (NIST 2017). The identified constituents were also confirmed by comparing it with the literature $[11,19,20]$.

\section{FTIR spectroscopic analysis}

FTIR spectrum of methanol extract of $Z$. armatum fruits was recorded in a sophisticated computercontrolled FTIR spectrometer (Shimadzu made, Tracer 100). $10 \mathrm{mg}$ of extract was loaded and scanned at the range of $4000-400 \mathrm{~cm}^{-1}$.

\section{Biological assays Cytotoxicity}

The brine shrimp lethality assay of the essential oil and methanol extract of $Z$. armatum was performed to evaluate cytotoxicity by following the standard protocol [12]. About $50 \mathrm{mg}$ of eggs of brine shrimp (Artemia salina) were sprinkled on the beaker filled with artificial seawater and illuminated with a table lamp (60 watts) for 48 hours by adjusting the temperature at $30{ }^{\circ} \mathrm{C}$. Stock solutions were prepared by dissolving $20 \mathrm{mg}$ of each extract and oil separately in DMSO in two separate test tubes. From each stock solution, solutions of $250 \mu \mathrm{g} / \mathrm{mL}, 125 \mu \mathrm{g} / \mathrm{mL}, 62.5$ $\mu \mathrm{g} / \mathrm{mL}, 31.25 \mu \mathrm{g} / \mathrm{mL}, 15.625 \mu \mathrm{g} / \mathrm{mL}$ and $7.81 \mu \mathrm{g} / \mathrm{mL}$ were prepared by serial dilution method. $2.5 \mathrm{~mL}$ of each concentration was transferred into test tubes, three for each concentration. Similarly, $2.5 \mathrm{~mL}$ of DMSO was taken in three test tubes as a blank. Labeling of test tubes was done and then they were kept for 24 hours to evaporate the solvent (DMSO). Then, the solvent was evaporated by standing overnight. After complete evaporation of the solvent, ten matured shrimps in 5 $\mathrm{mL}$ artificial seawater were transferred to all test tubes containing samples. Similarly, three controlled vials were taken and ten matured nauplii were introduced in each vial. After 24 hours of illumination under a table lamp (60 Watt), the numbers of survivors were counted with the help of disposable pipettes. The $\mathrm{LC}_{50}$ value (lethal concentration for 50\% mortality) was determined using probit regression. The compound of $\mathrm{LC}_{50}$ values less than $1000 \mathrm{ppm}$ are considered as potentially pharmacologically active [12].

\section{Antibacterial activity}

Inhibition of the bacterial growth by the samples was tested by using the agar well diffusion method $[13,15]$. The bacterial strains used in the assay were Klebsiella pneumonia (KCTC 2242), Bacillus subtilis (KACC 170477), Micrococcus leutus (KACC 1377), Pseudomonas aeruginosa (KACC 10232), Enterobacter cloacae (KAC 13002), and Staphylococcus aureus (KCTC 1916). About $100 \mu 1$ suspension of tested microorganisms were spread on the Muller-Hilton Agar medium. Wells having a diameter of $6 \mathrm{~mm}$ were made on the agar plates using the sterile cork borer. Essential oil and the methanol extract $(0.3 \mathrm{mg} /$ well $)$ were loaded separately in the wells along with solvent dimethyl sulfoxide (DMSO). Ciprofloxacin $(0.3 \mathrm{mg} /$ well $)$ was used as a positive control and DMSO as a negative control. The plates were then incubated at $37^{\circ} \mathrm{C}$ for $32 \mathrm{hrs}$. After incubation, the plates were observed for the diameter of the zone of inhibition (ZOI) in mm around the well. All tests were performed in triplicate.

\section{Antifungal activity}

Pure colonies of the fungal specimens (Aspergillus flavus, Fusarium solani) were inoculated into sterile 
Potato Dextrose Broth (PDB) and were kept in an incubator at $28^{\circ} \mathrm{C}$ for $72 \mathrm{hrs}$ for proper growth. After culture, $100 \mu \mathrm{L}$ of the broth was inoculated into the sterile Muller-Hilton Agar plate and spread uniformly. Following this, the disc previously soaked with $15 \mu \mathrm{L}$ of the sample (essential oil and methanol extract) were kept on the surface of the plate and kept at room temperature for 30 minutes to allow proper diffusion of the extract onto the medium. Miconazole was used as positive control and methanol was used as a negative control. The plates were left at $28^{\circ} \mathrm{C}$ for $48 \mathrm{hrs}$ and the results were observed. The experiment was done separately for essential oil and methanolic extract of the plant [14].

\section{DPPH radical scavenging activity}

DPPH radical scavenging activity of the extract and essential oil was determined by following the method of Sharma et al., (2015) [15]. Exactly weighed $7.886 \mathrm{~g}$ of the DPPH was dissolved in 100 $\mathrm{mL}$ methanol to prepare the $0.2 \mathrm{mM}$ solution. Briefly, for methanol extract, essential oil, and ascorbic acid (positive control), different concentrations $(12.5,25$, 50,100 , and $200 \mu \mathrm{g} / \mathrm{mL}$ ) were tested. From each concentration, $2 \mathrm{~mL}$ volume was taken and $2 \mathrm{~mL}$ of $0.2 \mathrm{~mm}$ DPPH solution was added. The absorbance of each final solution was taken on a UV-Visible spectrophotometer (UV professional double beam, Shimadzu made) at $517 \mathrm{~nm}$ after 30 minutes. The experiment for both methanol extract and essential oil was performed in triplicate and the percentage radical scavenging activity was calculated by using the following equation.

$\%$ radical scavenging activity $=\left(\mathrm{A}^{0}-\mathrm{A}^{1} / \mathrm{A}^{0}\right) \times 100 \%$

where, $\mathrm{A}^{0}=$ Absorbance of the control $(1 \mathrm{~mL} \mathrm{MeOH}+0.5$ $\mathrm{mL}$ DPPH).

$\mathrm{A}^{1}=$ Absorbance of the sample

The antioxidant activity result of each methanol extract, essential oil, and the positive control, ascorbic acid was expressed as an $\mathrm{IC}_{50}$ value. i.e. inhibitory concentration of the sample required to scavenge $50 \%$ of the free radicals and was calculated from the linear regression curve of concentration versus the percentage of free radical scavenging activity.

\section{Results and Discussion}

\section{Extraction}

Hydro distillation of fruits of $Z$. armatum yielded $7.8 \pm 0.5 \%$ (v/w) essential of light brown color having strong fragrance. The percentage yield of the extract was found to be $8.5 \%$.

\section{Phytochemical analysis}

Phytochemical screening revealed that the fruit of $Z$. armatum is rich in bioactive secondary metabolites. The qualitative result of the screening is presented in table 1 . The presence of these metabolites in the plant helps to show antimicrobial activities through different mechanisms [15].

Table 1: Phytochemical screening of fruit extract of Zanthoxylum armatum

\begin{tabular}{lclc}
\multicolumn{3}{c}{ Zanthoxylum armatum } \\
\hline Flavonoids & + & Tannins & + \\
Alkaloids & + & Volatile oils & + \\
Glycosides & + & Coumarins & - \\
Polyphenols & + & Saponin & + \\
Terpenoids & + & Protein and amino acids & - \\
Quinones & - & Reducing sugar & - \\
\hline
\end{tabular}

Key: + = Present $-=$ Absent

\section{GC-MS analysis}

The GC-MS analysis revealed the presence of at least six different compounds representing $99.27 \%$ of the oil (Table 2). Among the identified compounds, 3 were monoterpenes, 1 monoterpene alcohol, 1 ester, and 1 bicyclic sesquiterpene. Linalool (75.31\%, peak no. 4) was the major constituent followed by Emethyl cinnamate $(11.73 \%$, peak no. 5$)$ and limonene (9.45\%, peak no. 3). To the best of our knowledge, $Z$. armatum fruits from Nepal contain the highest percentage $(75.31 \%)$ of linalool [8,16,18-22].

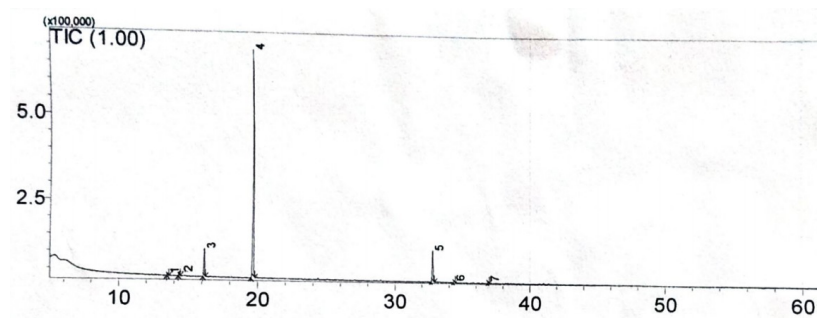

Figure 1: GC-MS chromatogram of essential oil of Z. armatum

Table 2: Chemical constituents of essential oil from $Z$. armatum fruits

\begin{tabular}{|c|c|c|c|c|}
\hline $\begin{array}{l}\text { Peak } \\
\text { No. }\end{array}$ & Compound & $\begin{array}{l}\text { Retention } \\
\text { time }\end{array}$ & $\begin{array}{l}\text { Area } \\
\%\end{array}$ & $\begin{array}{l}\text { Class of the } \\
\text { compound }\end{array}$ \\
\hline 1 & $\beta$-Pinene & 13.544 & 0.74 & Monoterpene \\
\hline 2 & Myrcene & 14.388 & 1.16 & Monoterpene \\
\hline 3 & Limonene & 16.173 & 9.45 & Monoterpene \\
\hline 4 & Linalool & 19.676 & 75.31 & $\begin{array}{l}\text { Monoterpene } \\
\text { alcohol }\end{array}$ \\
\hline 5 & $\begin{array}{l}\text { E-methyl } \\
\text { cinnamate }\end{array}$ & 32.771 & 11.73 & Ester \\
\hline 6 & $\begin{array}{l}\text { Cis- } \alpha- \\
\text { Bergamotene }\end{array}$ & 34.351 & 0.88 & $\begin{array}{l}\text { Bicyclic } \\
\text { sesquiterpene }\end{array}$ \\
\hline
\end{tabular}




\section{FTIR spectroscopic analysis}

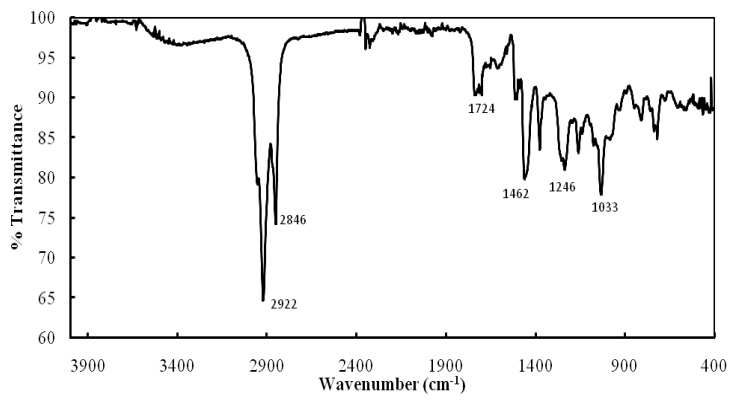

Figure 2: FTIR analysis of methanol extract of Z. armatum fruits

FTIR analysis was performed to identify the nature of functional groups of active components present in the methanol extract of $Z$. armatum fruits. FTIR spectroscopic analysis results (figure 2) revealed the presence of various characteristic functional groups at different peak values. The strong absorption peak at $2922 \mathrm{~cm}^{-1}$ and $2846 \mathrm{~cm}^{-1}$ showed the presence of $\mathrm{C}-\mathrm{H}$ stretching. The peak at $1724 \mathrm{~cm}^{-1}$ represented the presence of the $\mathrm{C}-\mathrm{O}$ stretch. The peak value at 1462 $\mathrm{cm}^{-1}$ represents the presence of $\mathrm{C}=\mathrm{C}$ stretch. The band at $1246 \mathrm{~cm}^{-1}$ denotes the $\mathrm{O}-\mathrm{H}$ absorption of alcohol and phenol. Similarly, the peak at $1033 \mathrm{~cm}^{-1}$ may arise due to the presence of a $\mathrm{C}-\mathrm{N}$ bond.

\section{Biological assays}

In the toxicity test, a brine-shrimp bioassay of the samples was performed and $\mathrm{LC}_{50}$ values were calculated. $\mathrm{LC}_{50}$ values for the essential oil and methanol extract were found to be $76.70 \mu \mathrm{g} / \mathrm{mL}$ and $62.25 \mu \mathrm{g} / \mathrm{mL}$ respectively. $\mathrm{LC}_{50}$ value is the lethal concentration dose required to kill $50 \%$ of the shrimps. Values less than $1000 \mu \mathrm{g} / \mathrm{mL}$ are supposed to be pharmacologically active [32]. So, Z. armatum is found to be cytotoxic against brine-shrimps as shown by the $\mathrm{LC}_{50}$ values much below the accepted maximum potential value of 1000 .

The results of the antibacterial screening and antifungal screening of the oil and extract of the plant are presented in tables 3 and 4 respectively. The antibacterial and antifungal activities against the pathogens examined were assessed by the presence or absence of inhibition zones.

The result of the antibacterial sensitivity test reveals that essential oil has high antibacterial activity against both gram-positive and gram-negative bacteria as compared to the standard ciprofloxacin. Gram-positive bacteria Bacillus subtilis $(11 \mathrm{~mm})$, Micrococcus leutus $(16 \mathrm{~mm})$, Staphylococcus aureus $(17 \mathrm{~mm})$ are found to be more sensitive than gram-negative bacteria Klebsiella pneumonia $(9 \mathrm{~mm})$, Enterobacter cloacae $(5 \mathrm{~mm})$, and Pseudomonas aeruginosa $(6 \mathrm{~mm})$ towards the essential oil. The presence of the highest amount of linalool (75.31\%), E-methyl cinnamate $(11.73 \%)$, and limonene $(9.45 \%)$ in the oil could be responsible

Table 3: Antibacterial activity of the volatile oil and methanol extract of Z. armatum fruits

\begin{tabular}{lllll}
\hline Test organism $(\mathbf{1 0 0} \boldsymbol{\mu L})$ & \multicolumn{3}{c}{ Zone of inhibition in $\mathbf{~ m m}$} \\
\cline { 2 - 5 } & $\begin{array}{l}\text { Essential oil }(0.3 \\
\mathrm{mg} / \mathrm{well})\end{array}$ & $\begin{array}{l}\mathrm{MeOH} \text { extract } \\
(0.3 \mathrm{mg} / \mathrm{well})\end{array}$ & $\begin{array}{l}\text { Ciprofloxacin }(0.3 \mathrm{mg} / \\
\text { well })\end{array}$ & DMSO \\
\hline Klebesiella pneumonalae & 9 & $\mathrm{NA}$ & 24 & $\mathrm{NA}$ \\
Bacillus subtilis & 11 & 7 & 26 & $\mathrm{NA}$ \\
Micrococcus leutus & 16 & 9 & 35 & $\mathrm{NA}$ \\
Enterobacter cloaceae & 5 & $\mathrm{NA}$ & 32 & $\mathrm{NA}$ \\
Pseudomonas aeruginosa & 6 & $\mathrm{NA}$ & 33 & $\mathrm{NA}$ \\
Staphylococus aureus & 17 & 11 & 38 & $\mathrm{NA}$ \\
\hline
\end{tabular}

Note: $N A=$ Not active (No ZOI was observed), Diameter of the well is $6 \mathrm{~mm}$

Table 4: Antifungal activity of the volatile oil and methanol extract of $Z$. armatum fruits

\begin{tabular}{lllll}
\hline \multirow{2}{*}{$\begin{array}{l}\text { Test } \\
\text { organism } \\
(\mathbf{1 0 0} \boldsymbol{\mu} \mathbf{L})\end{array}$} & \multicolumn{4}{c}{ Zone of inhibition in $\mathbf{~ m m}$} \\
\cline { 2 - 5 } & $\begin{array}{l}\text { Essential } \\
\text { oil }(15 \mu \mathrm{L})\end{array}$ & $\begin{array}{l}\mathrm{MeOH} \\
\text { extract } \\
(15 \mu \mathrm{L})\end{array}$ & Miconazole & Methanol \\
\hline $\begin{array}{l}\text { Aspergillus } \\
\text { flavus }\end{array}$ & 9 & 7 & 30 & NA \\
$\begin{array}{l}\text { Fusarium } \\
\text { solani }\end{array}$ & 5 & 4 & 29 & NA \\
\hline
\end{tabular}

for the high antibacterial activity of the essential oil from Nepal. Pattanaik et al., (1997) and Alviano et. al. (2005) reported the high antibacterial activity of linalool [17,23]. Moderate antibacterial activity had been previously reported for the essential oil of $Z$. armatum fruit [17]. The methanol extract of $Z$. armatum fruit showed moderate antibacterial activity compared to the essential oil. The extract could inhibit the growth of gram-positive bacteria only (Bacillus subtilis, Micrococcus leutus, and Staphylococcus 
aureus) with ZOI inhibition ranging 7-11 mm. Gramnegative bacteria Klebsiella pneumonia, Enterobacter cloacae, and Pseudomonas aeruginosa are found to be ineffective against the extract. Essential oil and the extract both showed moderate antifungal activity against the fungal strains Aspergillus flavus and Fusarium solani with ZOI ranging from 4 to $9 \mathrm{~mm}$ (Table 4). Previous studies also reported the moderate antifungal activity of $Z$. armatum $[18,19]$.

\section{DPPH radical scavenging activity}

The free radical scavenging activity of Zanthoxylum armatum fruit extract, essential oil, and the standard ascorbic acid was determined by using the DPPH assay. $\mathrm{IC}_{50}$ values (Table 5) were calculated by using the equations of the graphs obtained from the plot between \% radical scavenging activity and concentration. $\mathrm{IC}_{50}$ values of both extract and the essential oil are higher than that of the standard ascorbic acid $\left(\mathrm{IC}_{50}\right.$ value $\left.=39.55 \mu \mathrm{g} / \mathrm{mL}\right)$. If the $\mathrm{IC}_{50}$ value of samples is closer to that of ascorbic acid, then the samples are considered more potent in terms of free radical scavenging capacity [26]. Free radical scavenging capacity of extract $\left(\mathrm{IC}_{50}\right.$ value $=97.28 \mu \mathrm{g} /$ $\mathrm{mL}$ ) is found to be more than that of essential oil ( $\mathrm{IC}_{50}$ value $=174.47 \mu \mathrm{g} / \mathrm{mL}$ ). This variation is probably due to the difference in constituents present in the extract and essential oil. Essential oil chiefly contains the monoterpenes (Table 2) and the extract mainly contains the phytoconstituents having an antioxidant activity (Table 1).

Table 5: \% radical scavenging at different concentrations

\begin{tabular}{llll}
\hline \multicolumn{4}{c}{ and $C_{50}$ values } \\
\hline $\boldsymbol{N}(\boldsymbol{\mu g} / \mathbf{m L})$ & $\begin{array}{l}\text { \% Free radical scavenging } \\
\text { Methanol }\end{array}$ & $\begin{array}{l}\text { Essential } \\
\text { oil }\end{array}$ & $\begin{array}{l}\text { Ascorbic } \\
\text { acid }\end{array}$ \\
\hline 0 & 0 & 0 & 0 \\
12.5 & 9.88 & 4.76 & 48.58 \\
25 & 19.64 & 16.46 & 54.93 \\
50 & 35.75 & 24.29 & 67.76 \\
100 & 63.11 & 42.11 & 88.08 \\
200 & 86.94 & 49.71 & 96.02 \\
\hline $\mathbf{I C}_{\mathbf{5 0}} \mathbf{v a l u e}$ & 97.28 & 174.47 & 39.55 \\
$(\boldsymbol{\mu g} / \mathbf{m L})$ & & & \\
\hline
\end{tabular}

The presence of flavonoids and polyphenols in the extract may be responsible for the antioxidant activity [31]. Nooren et al., (2017) showed that flavonoids like tambulin are chiefly present in $Z$. armatum fruits [24]. Brijwal et al., (2013) and Phuyal et al., (2020) reported that the fruits of $Z$. armatum possess high antioxidant activity and this is due to the high amount of total phenolic and total flavonoids present in them $[25,26]$. Our findings are in agreement with Negi et al., (2012), Upadhaya et al., (2010), and Dhami et al., (2018) where the essential oil of $Z$. armatum fruits is found to more potent in terms of radical scavenging activity [27-29]. Singh et al., (2013) also reported that the essential oil of $Z$. armatum fruits from India exhibited high scavenging ability of DPPH radicals [30].

\section{Conclusion}

Chemical and biological studies of the essential oil and methanol extract of the fruit of $Z$. armatum have been carried out. GC-MS analysis of the oil showed a high concentration of Linalool $(75.31 \%)$ followed by E-methyl cinnamate $(11.73 \%)$ and limonene $(9.45 \%)$. The FTIR spectroscopic analysis of the methanol extract showed the presence of $\mathrm{C}-\mathrm{H}, \mathrm{C}=\mathrm{C}$, $\mathrm{O}-\mathrm{H}$, and $\mathrm{C}-\mathrm{N}$ bonds. Phytochemical screening of the methanol extract revealed the presence of alkaloids, flavonoids, glycosides, polyphenols, volatile oils, terpenoids, tannins, and saponins. From the study of brine shrimp bioassay, essential oil and extract were found to be cytotoxic against brine-shrimp nauplii having $\mathrm{LC}_{50}$ values $(\mu \mathrm{g} / \mathrm{mL}) 76.70$ and 62.25 respectively. Essential oil displayed high antibacterial activity against gram-positive bacteria and moderate antibacterial activity against gram-negative bacteria. However, the methanol extract is found to be effective against gram-positive bacteria only. Both oil and extract showed moderate antifungal activity against bacterial strains.

\section{Acknowledgments}

The authors are thankful to the Department of Chemistry, Amrit Campus, Tribhuvan University for providing the laboratory facility. Special thanks go to the Department of Plant Resources, Thapathali, Kathmandu, and the Central Department of Chemistry, Tribhuvan University, Kirtipur for providing the GCMS and FTIR facility respectively.

\section{References}

1. M. N. Mushtaq, S. Ghimire, M. S. Akhtar, A. Adhikari, C. Auger, and V. B. Schini-Kerth, Tambulin is a major active compound of a methanolic extract of fruits of Zanthoxylum armatum DC causing endothelium-independent relaxations in porcine coronary artery rings via the cyclic AMP and cyclic GMP relaxing pathways, Phytomedicine, 2019, 53, 163-170. (DOI: 10.1016/j.phymed.2018.09.020). 
2. A. Paul, A. Kumar, G. Singh, and A. Choudhary, Medicinal, pharmaceutical and pharmacological properties of Zanthoxylum armatum: A Review, Journal of Pharmacognosy and Phytochemistry, 2018, 7(4), 892-900.

3. M. Ibrar, N. Muhammad, A. Khan, S. A. Khan, S. Zafar, S. Jan, N. Riaz, Z. Ullah, U. Farooq, and J. Hussain. Pharmacognostic and phytochemical studies of Zanthoxylum armatum DC, Pakistan Journal of Pharmaceutical Sciences, 2017, 30(2), 429-438.

4. N.Phuyal, P.K. Jha, P.P. Raturiand S. Rajbhandary, Zanthoxylum armatum DC.: Current knowledge, gaps, and opportunities in Nepal, Journal of Ethnopharmacology, 2019, 229, 326-341. (DOI: 10.1016/j.jep.2018.08.010).

5. K. P. Devkota, J. Wilson, C. J. Henrich, J. B. McMahon, K. M. Reilly, and J. A. Beutler, Isobutylhydroxyamides from the pericarp of Nepalese Zanthoxylum armatum inhibit NF1defective tumor cell line growth, Journal of Natural Products, 2013, 76(1), 59-63. (DOI: 10.1021/np300696g).

6. L. Brijwal, A. Pandey and S. Tamta, An overview on phytomedicinal approaches of Zanthoxylum armatum DC, An important magical medicinal plant, Journal of Medicinal Plant Research, 7(8), 366-370. (DOI:10.5897/JMPR12.743).

7. R. Kanwal, M. Arshad, Y. Bibi, S. Asif, and S. K. Chaudhari, Evaluation of ethnopharmacological and antioxidant potential of Zanthoxylum armatum DC, Journal of Chemistry, 2015, 1, 1-9.

8. B. Barkatullah, M. Ibrar, N. Muhammad, I. U. Rehman, M. Rehman and A. Khan, Chemical composition and biological screening of essential oils of Zanthoxylum armatum DC leaves, Journal of Clinical Toxicology, 2014, 3(5), 1-6. (DOI: 10.4172/2161-0495.1000172).

9. T. P. Singh and O. M. Singh, Phytochemical and pharmacological profile of Zanthoxylum armatum DC. -An overview, Indian Journal of Natural Products and Resources, 2011, 2(3), 275-285.

10. A. J. Harborne, Phytochemical Methods A Guide to Modern Techniques of Plant Analysis. Springer Science \& Business Media, UK, 1998.

11. J. S. Negi, V. K. Bisht, A. K. Bhandari, P. Singh, and R. C. Sundriyal, Chemical constituents and biological activities of the genus Zanthoxylum: A review, African Journal of Pure and Applied Chemistry, 2011, 5(12), 412-416.

12. B. N. Meyer, N. R. Ferrigni, J. E. Putnam, L. B. Jacobsen, D. E. Nichols, and J. L. McLaughlin, Brine shrimp: A convenient general bioassay for active plant constituents, Planta Medica, 1982,
45(5), 31-34. (DOI: 10.1055/s-2007-971236).

13. B. Subba, A. Sharma, and A. Budhathoki, Assessment of phytochemical content, antioxidant and antibacterial activities of three medicinal plants of Nepal, Journal of Medicinal Plants Research, 2016, 10(45), 829-837. (DOI: 10.5897/ jmpr2016.6269).

14. S. Satish, D. C. Mohana, M. P. Raghavendra, and K. A. Raveesha, Antifungal activity of some plant extracts against important seed borne pathogens of Aspergillus sp., Journal of Agricultural Technology, 2007, 3(1), 109-119.

15. K. R. Sharma, S. K. Kalauni and S. Awale, Antioxidant, phytotoxic and antimicrobial activities of methanolic extract of Bauhinia variegata barks, Journal of Institute of Science and Technology, 2015, 20(2), 37-41. (DOI:10.3126/ jist.v20i2.13946).

16. C. F. Wang, W. J. Zhang, C. X. You, S. S. Guo, J. F. Geng, L. Fan, S. S. Du and Y. Y. Wang, Insecticidal constituents of essential oil derived from Zanthoxylum armatum against two storedproduct insects, Journal of Oleo Science, 2015, 64(8), 861-868. (DOI:10.5650/jos.ess15068).

17. S. Pattanaik, V. R. Subramanyam, M. Bapaji and C. R. Kole, Antibacterial and antifungal activity of aromatic constituents of essential oils, Microbios, 1997, 89(358), 39-46.

18. D. Bisht and C. S. Chanotiya, 2-Undecanone rich leaf essential oil from Zanthoxylum armatum, Natural Products Communication, 2011, 6(1), 111-114. (DOI.org/10.1177/193457 8X1100600126).

19. M. Tiwary, S. N. Naik, D. K. Tewary, P. K. Mittal and S. Yadav, Chemical composition and larvicidal activities of the essential oil of Zanthoxylum armatum DC (Rutaceae) against three mosquito vectors, Journal of Vector-borne Diseases, 2007, 44,198-204.

20. A. Waheed, S. Mahmud, M. Akhtar, and T. Nazir, Studies on the components of essential oil of Zanthoxylum Armatum. American Journal of Analytical Chemistry, 2011, 2(2), 258-261.

21. G. Singh, I. P. Kapoor, P. Singh, C. S. Heluani, M. P. Lampasona, and C. N. Catalan, Chemistry and antioxidant properties of essential oil and oleoresins extracted from the seeds of tomer (Zanthoxylum armatum DC), International Journal of Food Properties, 16(2), 288-300.

22. A. Ahmed, L. N. Misra, and M. M. Gupta, Hydroxyalk-(4Z)-enoic acids and volatile components from the seeds of Zanthoxylum armatum. Journal of Natural Products, 1993, 56(4), 456-460. 
23. W. S. Alviano, H. R. Bizzo, P. T. Souto, M. L. Rodrigues and M. G. Souza, Antimicrobial activity of croton cajucara benth linalool-rich essential oil on artificial biofilms and planktonic microorganisms. Oral Microbiology and Immunology, 2005, 20(2), 101-105.

24. Z. Nooreen, S.Singh, D. K. Singh, S. Tandon, A. Ahmad and S. Luqman, Characterization and evaluation of bioactive polyphenolic constituents from Zanthoxylum Armatum DC., a traditionally used plant, Biomedicine and Pharmacotherapy, 2017, 89, 366-375. (https://doi.org/10.1016/j. biopha.2017.02.040).

25. L. Brijwal, A. Pandey and S. Tamta, An Overview on phytomedicinal approaches of Zanthoxylum armatum DC., An important magical medicinal plant, Journal of Medicinal Plants Research, 2013,7(8), 366-370. (https://doi.org/10.5897/ JMPR12.743).

26. N. Phuyal,P. K. Jha, P. P. Raturi and S. Rajbhandary, Total phenolic, flavonoid contents, and antioxidant activities of fruit, seed, and bark extracts of Zanthoxylum armatum DC, The Scientific World Journal, 2020, 1, 1-7. (https:// doi.org/10.1155/2020/8780704).

27. J. S. Negi, V. K. Bisht, A. K. Bhandari, R. Bisht and K. S. Negi, Major constituents, antioxidant and antibacterial activities of Zanthoxylum armatum DC. essential oil, Iranian Journal of Pharmacology and Therapeutics, 2012, 11(2), 68-75.
28. K. Upadhyaya and A. P. Kumar, Concentrationdependent antioxidant activity of Zanthoxylum armatum, Journal of Pharmacy Research, 2010, 3(7), 1581-1582.

29. A. Dhami, D, Palariya, A. Singh, R. Kumar, O. Prakash, R. Kumar, and A, Pant, Chemical composition, antioxidant, in vitro antiinflammatory and antibacterial activity of seeds essential oil of Zanthoxylum armatum DC collected from two different altitudes of Kumaun region, Uttarakhand, International Journal of Chemical Studies, 2018, 6(6), 363-370.

30. G. Singh, I. P. S. Kapoor, P. Singh, C. S. Heluani, M. P. Lampasona, and C. A. N. Catalan, Chemistry and antioxidant properties of essential oil and oleoresins extracted from the seeds of tomer (Zanthoxylum armatum DC), International Journal of Food Properties, 2013, 16 (2), 288-300. (https:// doi.org/10.1080/10942912.2010.551311).

31. I. Pathak and M. Niraula, Assessment of total phenolic, flavonoid content and antioxidant activity of Ocimum sanctum Linn. Journal of Nepal Chemical Society, 2019, 40, 30-35. (https:// doi.org/10.3126/jncs.v40i0.27275).

32. D. Basyal and N. L. Bhandari, Phytochemical screening and cytotoxicity evaluation of ethanolic extract of Hypericum cordifolium (Choisy) leaves. Journal of Nepal Chemical Society, 2019, 40, 1924. (https://doi.org/10.3126/jncs.v40i0.27273). 